\title{
Spawanie hartowanej stali Boron 27 Dobór spoiwa i parametrów spawania
}

\section{Welding Boron 27 steel in the hardened state Selection of filler and welding parameters}

\section{Streszczenie}

Przeprowadzono badania w zakresie doboru spoiwa i parametrów spawania hartowanej stali Boron 27, a także zbadano właściwości wytrzymałościowe otrzymanych połączeń doczołowych. Zastosowano spoiwa ESAB OK. Autorod 12.64, ESAB OK. AristoRod 13.29, BÖHLER X 70-IG, EASB OK. Tubrod 15.14. Dla spoiwa EASB OK. Tubrod 15.14 nie uzyskano poprawnych parametrów spawania w zakresie badań wizualnych. W wyniku badań na rozciąganie próbek stwierdzono, że pękały one w strefie wpływu ciepła, a właściwości wytrzymałościowe nie różniły się w sposób istotny dla wszystkich zastosowanych spoiw. Badania na zginanie pokazały jednak, że pozytywnie przeszły próbę próbki spawane spoiwami ESAB OK. Autorod 12.64 i ESAB OK. AristoRod 13.29.

Słowa kluczowe: stal hartowania, spoiwo, parametry

\section{Abstract}

The research was conducted in the field of the selection of filler and welding parameters for hardened Boron 27 steel. The endurance properties of the obtained frontal joints were also tested. The following fillers were applied: ESAB OK. Autorod 12.64, ESAB OK. AristoRod 13.29, BÖHLER X 70-IG, EASB OK. Tubrod 15.14. Appropriate welding parameters were not attained for the filler EASB OK. Tubrod 15.14 (visual examination). The tensile strength tests on the samples resulted in their fractures in the heat-affected zones. The endurance properties did not significantly vary as far as all the applied fillers are concerned. However, the bending strength tests gave a positive result for the samples welded with the following fillers: ESAB OK. Autorod 12.64 and ESAB OK. AristoRod 13.29.

Key words: hardened steel, filler metal, parameters

\section{Wstęp}

Elementy maszyn rolniczych, takie jak: lemiesze pługów, części bron, kultywatorów, elementy robocze kosiarek, zgrabiarek, przetrząsaczy itp., pracują w warunkach sprzyjających intensywnemu procesowi zużywania ściernego. Stykają się ciągle $z$ materiałami w postaci ziaren piasku, różnymi częściami roślin, w tym z twardymi łodygami krzewów i młodych drzew. Od takich elementów wymagana jest zatem duża odporność na ścieranie, a ze względu na znaczne obciążenia zewnętrzne podczas ich eksploatacji - charakteryzować się powinny korzystnymi właściwościami wytrzymałościowymi.

Odporność na zużywanie ścierne elementów maszyn jest zależna od twardości względnej materiału ściernego (w stosunku do materiału ulegającego zużywaniu), nacisków jednostkowych, częstości wymiany tych produktów w obszarach tarcia, prędkości poślizgu i wielu innych czynników. W przypadku elementów maszyn rolniczych, na niektóre z warunków sprzyjających zużywaniu ściernemu nie mamy wpływu, możemy jedynie wpływać na twardość materiału tych elementów. Ponieważ między względną odpornością na zużycie ścierne a twardością stali różnych gatunków występuje liniowa zależność [1], na elementy maszyn narażone na zużywanie ścierne należy stosować materiały o możliwie największej twardości.

Dużą twardość stali uzyskuje się w procesie hartowania. Po hartowaniu stal wykazuje jednak bardzo małą plastyczność. Niektóre elementy robocze maszyn rolniczych mają przestrzenne kształty i mogą być wykonywane tylko metodą tłoczenia przy zastosowaniu dodatkowo spawania przy ich łączeniu. Przy małej plastyczności materiału technologia tłoczenia nie jest możliwa do zastosowania.

Dobrą plastycznością charakteryzuje się stal borowa Boron 27. Ponadto, jak podaje producent, stal ta jest spawalna i nadaje się do hartowania. Po hartowaniu można uzyskać twardość 380 HB.

Mgr inż. Wojciech Czaplejewicz, dr hab. inż. Zdzisław Kondrat - Politechnika Białostocka.

Autor korespondencyjny/Corresponding author: wojtek-iwona@o2.pl 
Możliwość spawania stali Boron 27 potwierdzają wyniki badań przedstawione w [2]. Autorzy tej pracy przeprowadzili także hartowanie spawanych doczołowo płyt. Okazało się jednak, że w wyniku hartowania płyty uległy znacznemu zniekształceniu. Wykonano również próbę spawania dwóch wytłoczek stanowiących półwyroby do zespołu tnącego kosiarki, a następnie poddano je zahartowaniu. Wystąpiły tak duże odkształcenia, że część ta nie nadawała się do montażu. Zahartowano oddzielnie dwie wytłoczki i pospawano je. Odkształcenia powstałe w detalu były znikome i akceptowalne. Dlatego też podjęto badania w zakresie doboru spoiwa i parametrów spawania hartowanej stali Boron 27 oraz określenia właściwości wytrzymałościowych otrzymanych połączeń doczołowych.

\section{Charakterystyka stali Boron 27}

Równoważnik węgla CEV dla stali Boron 27 wynosi 0,56 , a jej skład chemiczny zawarto w tablicy I.

Stal ta wykazuje takie korzystne cechy, jak:

- w stanie po hartowaniu wykazuje bardzo dobrą odporność na ścieranie;

- w stanie niehartowanym można ją tłoczyć;

- ze względu na niską zawartość węgla jest spawalna.

Do wykonania złączy spawanych użyto blachy o grubości $4 \mathrm{~mm}$.

\section{Wybór spoiwa}

Dobierając spoiwo do spawania materiałów konstrukcyjnych, należy wziąć pod uwagę w pierwszej kolejności jego granicę plastyczności $R_{e}$. Wartość granicy plastyczności spoiwa nie powinna być niższa niż dla materiału spawanego. Teoretycznie można dopuścić spoiwo o niższej granicy plastyczności, gdy naprężenia eksploatacyjne w spoinach są małe i nie są one krytyczne dla konstrukcji. Mniejsze znaczenie w doborze spoiwa ma jego wytrzymałość na rozciąganie $R_{m}$, ponieważ stosunek granicy plastyczności do wytrzymałości spoiwa jest na ogół wyższy niż dla materiału podstawowego.

Drugą istotną wielkością jest udarność (KV) spoiwa w określonej temperaturze, będąca miernikiem jego przydatności do spawania stali przeznaczonej na konstrukcje narażone na pękanie. Spoiwo dobrane według tego kryterium powinno mieć wyższą udarność niż materiał podstawowy. W przypadku spawania różnych gatunków stali należy przyjąć zasadę, że właściwości mechaniczne spoiwa $\left(R_{e}, R_{m}, K V\right)$ powinny spełniać wymagania dla tej o wyższych właściwościach.

Dobór spoiwa pod względem dopasowania składu chemicznego nie jest tak prosty jak w przypadku doboru wytrzymałości i udarności. Węgiel, niezależnie od przeznaczenia i wytrzymałości spoiwa, niekorzystnie wpływa na spawalność, podnosząc skłonność do pękania spoin. Występuje w spoiwie z reguły w ilości nie większej niż $0,1 \%$.

Wzrost wytrzymałości spoiwa uzyskuje się przez zwiększenie zawartości manganu. Mangan, podobnie jak krzem, ulega częściowemu wypaleniu w aktywnych atmosferach łuku elektrycznego, więc jego zawartość w spoiwie powinna być wyższa niż w spawanym materiale.

Do spoiw o wysokiej wytrzymałości wprowadza się również dodatek molibdenu, a nawet chromu. Przy zwiększonej zawartości Mn, Cr i Mo pogarsza się jednak spawalność w wyniku wzrostu hartowności, dlatego do spoiwa wprowadza się również nikiel, który zmniejsza krytyczną szybkość chłodzenia, poprawia plastyczność i podnosi odporność spoiny na pękanie.

Dobór spoiwa według powyższych kryteriów nie jest oczywisty, szczególnie, że materiałem spawanym jest stal w stanie zahartowanym. Hartowana stal borowa, jak pokazano w tablicy II, ma bardzo wysokie wartości $R_{e}$ i $R_{m} i$ żadne spoiwo, z proponowanych przez producenta stali, nie sprosta wymaganiom wytrzymałościowym.

Korzystając ze standardowych krzywych twardość-odpuszczanie (rys. 1), można przypuszczać, że w SWC wartości $R_{e}$ i $K V$ będą nieznacznie wyższe od tych dla rodzimego materiału nieobrobionego cieplnie. Biorąc pod uwage powyższe rozważania, dobrano spoiwa:

- ESAB OK Autorod 12.64 - dalej oznaczane w badaniach Z12 - G4Si1 wg PN-EN ISO 14341:2011 [4],

Tablica I. Zawartość składników stopowych wg atestu materiałowego Table I. Content of alloy constituents according to material certificate

\begin{tabular}{|c|c|c|c|c|c|c|c|c|c|c|c|c|}
\hline \multicolumn{10}{|c|}{ Zawartość składników stopowych, \% wag. } \\
\hline $\mathrm{C}$ & $\mathrm{Si}$ & $\mathrm{Mn}$ & $\mathrm{P}$ & $\mathrm{S}$ & $\mathrm{Al}$ & $\mathrm{V}$ & $\mathrm{Ti}$ & $\mathrm{Cu}$ & $\mathrm{Cr}$ & $\mathrm{Ni}$ & $\mathrm{Mo}$ & $\mathrm{B}$ \\
\hline 0,284 & 0,26 & 1,25 & 0,008 & 0,007 & 0,042 & 0,011 & 0,044 & 0,026 & 0,31 & 0,05 & 0,005 & 0,0022 \\
\hline
\end{tabular}

Tablica II. Właściwości mechaniczne - dane producenta i badania własne

Table II. Mechanical properties - manufacturer's data and own research

\begin{tabular}{|c|c|c|c|c|c|c|c|}
\hline \multirow{2}{*}{\multicolumn{2}{|c|}{ Stan materiału }} & \multirow{2}{*}{$\begin{array}{c}\text { Granica } \\
\text { plastyczności } \\
\mathrm{R}_{\mathrm{e}}, \mathrm{MPa}\end{array}$} & \multirow{2}{*}{$\begin{array}{c}\text { Wytrzymałość } \\
\text { na rozciąganie } \\
\mathrm{R}_{\mathrm{m}}, \mathrm{MPa}\end{array}$} & \multirow{2}{*}{$\begin{array}{c}\text { Wydłużenie } \\
\qquad A_{5}, \%\end{array}$} & \multirow{2}{*}{$\begin{array}{c}\text { Twardość } \\
\text { HB }\end{array}$} & \multicolumn{2}{|c|}{ Udarność } \\
\hline & & & & & & $\mathrm{T},{ }^{\circ} \mathrm{C}$ & $\mathrm{KV}, \mathrm{J}$ \\
\hline \multicolumn{2}{|c|}{ B27 niehartowana } & ok. 420 & ok. 620 & 25 & 170 & - & - \\
\hline \multirow{3}{*}{$\begin{array}{c}\text { B27 } \\
\text { hartowana }\end{array}$} & olej & 1000 & 1250 & 8 & 380 & - & - \\
\hline & woda & 1200 & 1600 & 6 & 460 & -40 & 20 \\
\hline & $\begin{array}{c}\text { woda, bada- } \\
\text { nia własne }\end{array}$ & 1197 & 1678 & - & - & - & - \\
\hline
\end{tabular}


- ESAB OK AristoRod 13.29 (69) - dalej oznaczane w badaniach Z69 - G 694 M Mn3Ni1CrMo wg PN-EN ISO 14341:2011 [4],

- BÖHLER X 70-IG - dalej w badaniach oznaczane ZX70 - G 695 M Mn3Ni1CrMo wg PN-EN ISO 14341:2011 [4],

- ESAB OK Tubrod 15.14 - dalej w badaniach oznaczane Z15 - T 462 PM 1 H5 wg PN-EN ISO 17632:2011 [5].

Do spawania użyto zalecanej przez producenta mieszaniny gazowej M21 o składzie $82 \% \mathrm{Ar}+18 \% \mathrm{CO}_{2}$ wg PN-EN ISO 14175:2009 [6].

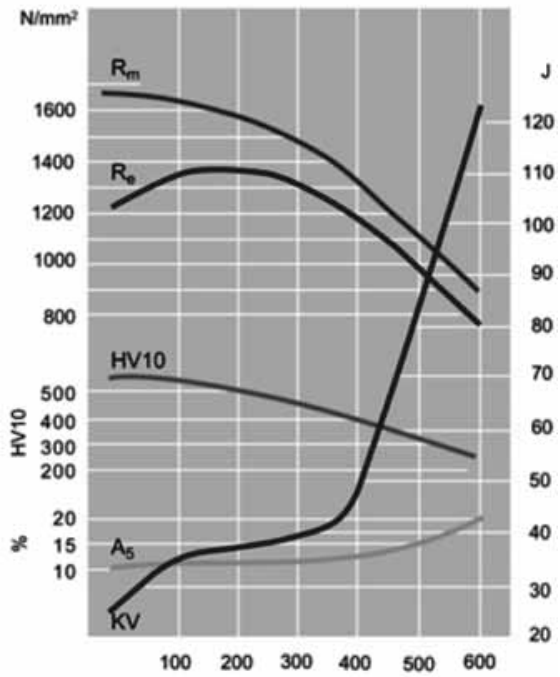

Rys. 1. Standardowe krzywe twardość-odpuszczanie dla gatunków stali borowych B27 $w$ temperaturze austenityzowania $920^{\circ} \mathrm{C}$ [3]: $R_{m}$ - wytrzymałość na rozciąganie $\mathrm{N} / \mathrm{mm}^{2} ; R_{\mathrm{e}}$ - granica plastyczności, $\mathrm{N} /$ $\mathrm{mm}^{2} ; \mathrm{A}_{5}$ - wydłużenie, \%; KV - udarność, J $\left(+20^{\circ} \mathrm{C}\right) ; \mathrm{HV}$ - twardość Fig. 1. Standard curves hardness-tempering for types of B27 boron steel at austenitising temperature of $920^{\circ} \mathrm{C}$ [3]: $R_{m}$ - tensile strength, $\mathrm{N} / \mathrm{mm}^{2} ; R_{\mathrm{e}}$ - yield point, $\mathrm{N} / \mathrm{mm}^{2} ; \mathrm{A}_{5}$ - elongation, \%; KV - impact resistance, $\mathrm{J}\left(+20^{\circ} \mathrm{C}\right) ; \mathrm{HV}$ - hardness

\section{Dobór parametrów spawania dla poszczególnych spoiw}

Do spawania użyto zahartowanych w wodzie do twardości $50 \pm 2$ HRC płyt o wymiarach 150 x $300 \mathrm{~mm}$ z blachy o grubości $4 \mathrm{~mm}$. Łączono je ze sobą spoinami o długości $100 \mathrm{~mm}$ metodą 135, przy czym każda spoina wykonana została przy innych parametrach spawania (tabl. III $\div \mathrm{VI}$ ). Dla każdego spoiwa wykonano jedną płytę próbną (składającą się z trzech płyt $150 \times 300 \mathrm{~mm}$ ), a na niej 9 spoin (rys. 2).

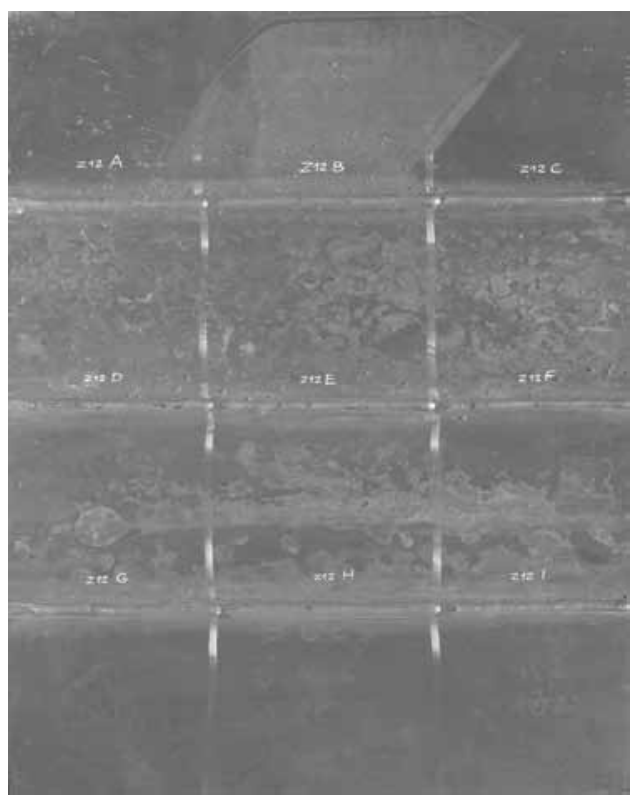

Rys. 2. Przykładowa płyta próbna dla spoiwa $Z 12$

Fig. 2. Specimen of sample slab for filler $Z 12$

Tablica III. Parametry spawania płyt próbnych dla spoiwa Z12

Table III. Welding parameters of sample slabs for filler Z12

\begin{tabular}{|c|c|c|c|c|c|c|c|c|c|}
\hline \multirow{2}{*}{ Parametry } & \multicolumn{6}{|c|}{ Zwarcie } & \multicolumn{3}{|c|}{ Puls } \\
\hline & Z12A & Z12B & Z12C & Z12D & Z12E & Z12F & Z12G & $\mathrm{Z12H}$ & Z12I \\
\hline Prąd spawania, A & 130 & 120 & 110 & 160 & 150 & 140 & 130 & 120 & 110 \\
\hline Napięcie łuku, V & 19,1 & 18,8 & 18,5 & 20,3 & 19,7 & 19,4 & 25,2 & 24,6 & 24,0 \\
\hline Prędkość podawania drutu, $\mathrm{m} / \mathrm{min}$ & 4,4 & 4,0 & 3,6 & 5,7 & 5,2 & 4,8 & 5,0 & 4,6 & 4,2 \\
\hline Prędkość spawania, cm/min & \multicolumn{9}{|c|}{ ok. 25} \\
\hline Natężenie wypływu gazu, I/min & \multicolumn{9}{|c|}{$12-15$} \\
\hline
\end{tabular}

Tablica IV. Parametry spawania płyt próbnych dla spoiwa Z69

Table IV. Welding parameters of sample slabs for filler Z69

\begin{tabular}{|c|c|c|c|c|c|c|c|c|c|}
\hline \multirow{2}{*}{ Parametry } & \multicolumn{6}{|c|}{ Zwarcie } & \multicolumn{3}{|c|}{ Puls } \\
\hline & Z69A & Z69B & Z69C & Z69D & Z69E & Z69F & Z69G & $\mathrm{Z69H}$ & Z69l \\
\hline Prąd spawania, $A$ & 130 & 120 & 110 & 160 & 150 & 140 & 130 & 120 & 110 \\
\hline Napięcie łuku, V & 19,1 & 18,8 & 18,5 & 20,3 & 19,7 & 19,4 & 25,2 & 24,6 & 24,0 \\
\hline Prędkość podawania drutu, $\mathrm{m} / \mathrm{min}$ & 4,4 & 4,0 & 3,6 & 5,7 & 5,2 & 4,8 & 5,0 & 4,6 & 4,2 \\
\hline Prędkość spawania, cm/min & \multicolumn{9}{|c|}{ ok. 25} \\
\hline Natężenie wypływu gazu, I/min & \multicolumn{9}{|c|}{$12-15$} \\
\hline
\end{tabular}


Tablica V. Parametry spawania płyt próbnych dla spoiwa ZX70

Table V. Welding parameters of sample slabs for filler ZX70

\begin{tabular}{|c|c|c|c|c|c|c|c|c|c|}
\hline \multirow{2}{*}{ Parametry } & \multicolumn{6}{|c|}{ Zwarcie } & \multicolumn{3}{|c|}{ Puls } \\
\hline & ZX70A & ZX70B & ZX70C & ZX70D & ZX70E & ZX70F & ZX70G & $\mathrm{ZX70H}$ & ZX70I \\
\hline Prąd spawania, A & 130 & 120 & 110 & 160 & 150 & 140 & 130 & 120 & 110 \\
\hline Napięcie łuku, V & 18,1 & 17,8 & 17,5 & 19,1 & 18,8 & 18,5 & 23,9 & 23,4 & 22,7 \\
\hline Prędkość podawania drutu, m/min & 4,5 & 4,0 & 3,7 & 6,0 & 5,5 & 5,0 & 7,0 & 6,4 & 5,7 \\
\hline Prędkość spawania, cm/min & & & & & ok. 25 & & & & \\
\hline Natężenie wypływu gazu, l/min & & & & & $12-15$ & & & & \\
\hline
\end{tabular}

Tablica VI. Parametry spawania płyt próbnych dla spoiwa Z15

Table VI. Welding parameters of sample slabs for filler Z15

\begin{tabular}{|c|c|c|c|c|c|c|c|c|c|}
\hline \multirow{2}{*}{ Parametry } & \multicolumn{6}{|c|}{ Zwarcie } & \multicolumn{3}{|c|}{ Puls } \\
\hline & Z15A & Z15B & Z15C & Z15D & Z15E & Z15F & Z15G & $\mathrm{Z15H}$ & Z15I \\
\hline Prąd spawania, A & 175 & 165 & 155 & 205 & 195 & 185 & 175 & 165 & 155 \\
\hline Napięcie łuku, V & 19,3 & 18,7 & 18,3 & 20,9 & 20,5 & 19,9 & 24,7 & 24,3 & 23,9 \\
\hline Prędkość podawania drutu, m/min & 4,5 & 4,1 & 3,8 & 5,6 & 5,3 & 4,9 & 5,9 & 5,6 & 5,3 \\
\hline Prędkość spawania, cm/min & \multicolumn{9}{|c|}{ ok. 25} \\
\hline Natężenie wypływu gazu, I/min & \multicolumn{9}{|c|}{$12-15$} \\
\hline
\end{tabular}

Tablica VII. Parametry spawania, dla których spoina spełnia kryteria akceptacji

Table VII. Welding parameters to be attained for weld to meet criteria for acceptance

\begin{tabular}{|c|c|c|c|c|c|c|c|c|}
\hline Spoiwo & Proces & $\begin{array}{l}\text { Średnica } \\
\text { drutu, mm }\end{array}$ & $\begin{array}{c}\text { Prąd } \\
\text { spawania, } A\end{array}$ & $\begin{array}{l}\text { Napięcie } \\
\text { łuku, V }\end{array}$ & $\begin{array}{c}\text { Rodzaj } \\
\text { prądu/ } \\
\text { biegunowość }\end{array}$ & $\begin{array}{l}\text { Prędkość } \\
\text { pod. drutu } \\
\mathrm{m} / \mathrm{min}\end{array}$ & $\begin{array}{l}\text { Prędkość } \\
\text { spawania } \\
\text { cm/min }\end{array}$ & $\begin{array}{c}\text { Energia } \\
\text { liniowa } \\
\mathrm{kJ} / \mathrm{cm}\end{array}$ \\
\hline Z12 & 135 & 1,0 & 120 & 18,8 & $\mathrm{DC} /+$ & 4 & $\sim 25$ & $\max 4,0$ \\
\hline Z69 & 135 & 1,0 & 120 & 18,8 & DC/+ & 4 & $\sim 25$ & $\max 4,3$ \\
\hline ZX70 & 135 & 1,0 & 130 & 18,1 & DC/+ & 4,5 & $\sim 25$ & $\max 4,7$ \\
\hline
\end{tabular}

Do spawania zastosowano źródło ESAB AristoMig 500iw.

Każdą spoinę poddano badaniom wizualnym wg PNEN ISO 17637:2011 [7]. Wybrano parametry spawania, dla których spoina spełnia kryteria akceptacji - poziom jakości B wg PN-EN ISO 17637:2011 [7]; zawarto je w tablicy VII.

Dla spoiwa Z15 nie znaleziono parametrów, przy których spoiny można byłoby uznać za poprawne. Spoiwo to nie będzie brane pod uwagę w dalszych badaniach.

\section{Wyniki badań złączy płyt kontrolnych}

Stosując zestawione w tablicy VII parametry, spawano 6 płyt, uzyskując po dwie płyty kontrolne dla każdego rodzaju spoiwa i oznaczono je symbolami: Z12-I, Z12-II, Z69-I, Z69-II, ZX70-I, ZX70-II. Przykładową płytę kontrolną pokazano na rysunku 3.

Badania rentgenowskie wykonano w akredytowanym Laboratorium Badań Nieniszczących Instal Białystok S.A. Wyniki badań zestawiono w tablicy VIII.

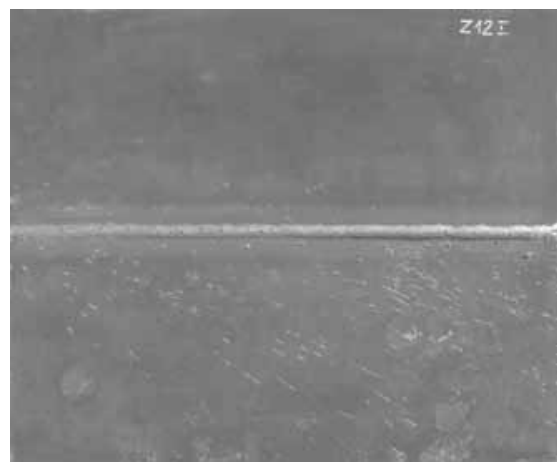

Rys. 3. Przykładowa płyta kontrolna

Fig. 3. Example of control slab

Tablica VIII. Wyniki badań rentgenowskich

Table VIII. X-ray examination results

\begin{tabular}{|c|c|c|c|}
$\begin{array}{c}\text { Nr płyty } \\
\text { kontrolnej }\end{array}$ & $\begin{array}{c}\text { Stwierdzone } \\
\text { niezgodności }\end{array}$ & $\begin{array}{c}\text { Poziom } \\
\text { jakości }\end{array}$ & $\begin{array}{c}\text { Nr } \\
\text { protokołu }\end{array}$ \\
\cline { 1 - 3 } Z12-I & 515 & $\mathrm{~B}$ & \multirow{2}{*}{$314 / 10$} \\
\cline { 1 - 3 } Z12-II & 5013 & $\mathrm{~B}$ & \\
\cline { 1 - 3 } Z69-I & 5011 & $\mathrm{~B}$ & \multirow{2}{*}{$315 / 10$} \\
\cline { 1 - 3 } Z69-II & 2011 & $\mathrm{~B}$ & \multirow{2}{*}{$316 / 10$} \\
\hline ZX70-I & 5011 & $\mathrm{~B}$ & \\
\hline ZX70-II & 5011 & $\mathrm{~B}$ & \\
\cline { 1 - 3 }
\end{tabular}


Przeprowadzono wg PN-EN ISO 4136:2011 [8] badania wytrzymałości na rozciąganie próbek ze złączy spawanych. W tym celu z każdej płyty kontrolnej wycięto po 3 próbki o kształcie i wymiarach wg rysunku 4 . Wszystkie próbki pę-

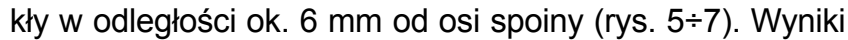
zestawiono w tablicy IX.

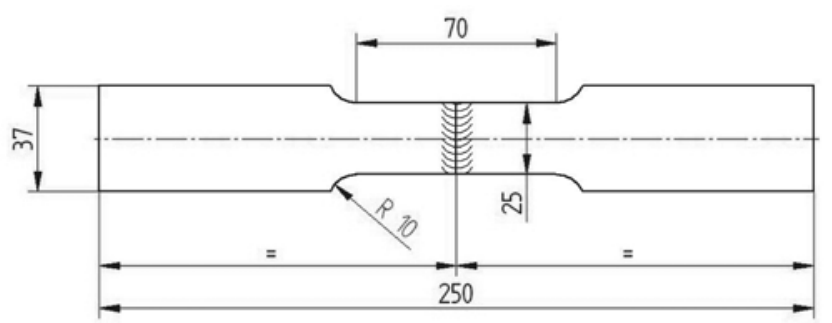

Rys. 4. Próbka do badań na rozciąganie (rozrywanie)

Fig. 4. Sample for tensile (tearing apart) strength tests

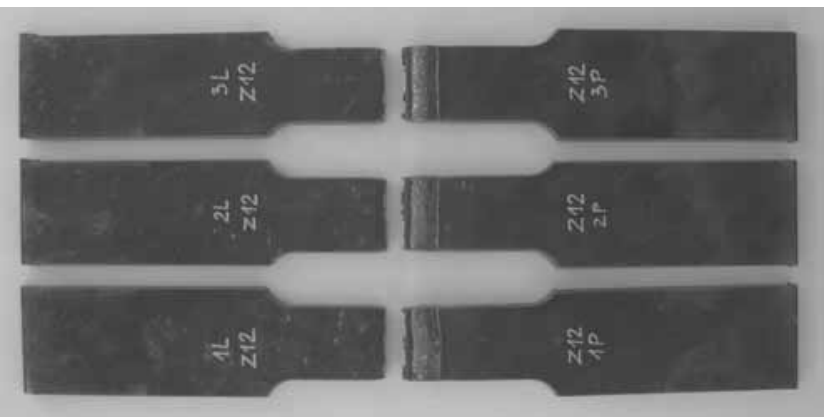

Rys. 5. Zerwane próbki łączone spoiwem Z12

Fig. 5. Torn samples joined with filler Z12

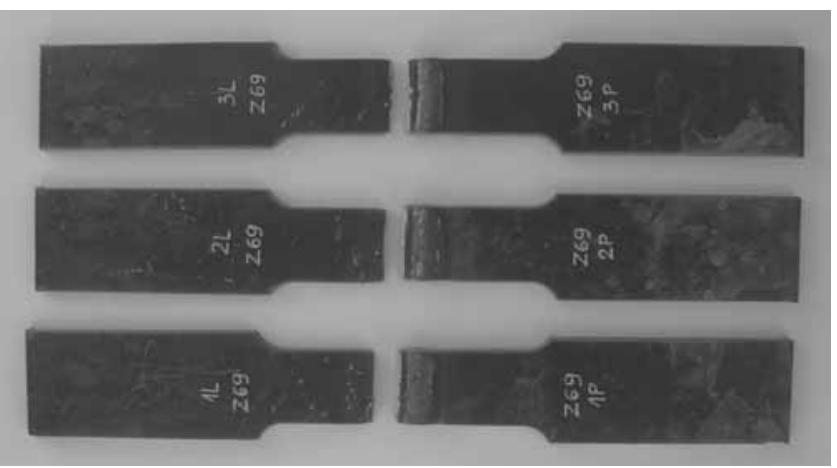

Rys. 6. Zerwane próbki łączone spoiwem Z69

Fig. 6. Torn samples joined with filler Z69

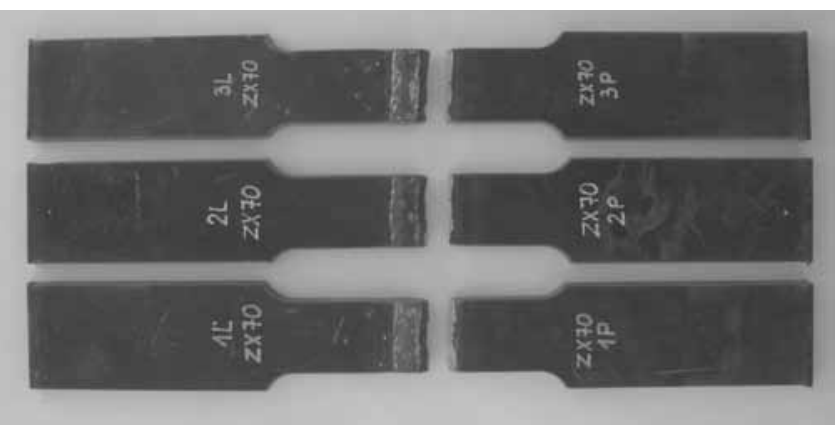

Rys. 7. Zerwane próbki łączone spoiwem ZX70

Fig. 7. Torn samples joined with filler ZX70
Tablica IX. Wyniki próby rozciągania

Table IX. Tensile test results

\begin{tabular}{|c|c|c|c|}
\hline $\begin{array}{c}\text { Oznaczenie } \\
\text { próbki }\end{array}$ & $\begin{array}{c}\text { Wytrzymałość } \\
\text { na rozciąganie } \\
\mathrm{R}_{\mathrm{m}}, \mathrm{MPa}\end{array}$ & $\begin{array}{c}\text { Umowna } \\
\text { granica } \\
\text { sprężystości } \\
\mathrm{R}_{0.05}, \mathrm{MPa}\end{array}$ & $\begin{array}{c}\text { Umowna } \\
\text { granica } \\
\text { plastyczności } \\
\mathrm{R}_{0,2}, \mathrm{MPa}\end{array}$ \\
\hline Z12 Pr. nr 1 & 918 & 637 & 738 \\
\hline Z12 Pr. nr 2 & 925 & 588 & 718 \\
\hline Z12 Pr. nr 3 & 943 & 562 & 722 \\
\hline Średnia & $\mathbf{9 2 8 , 7}$ & $\mathbf{5 9 5 , 7}$ & $\mathbf{7 2 6}$ \\
\hline Z69 Pr. nr 1 & 930 & 525 & 683 \\
\hline Z69 Pr. nr 2 & 922 & 519 & 630 \\
\hline Z69 Pr. nr 3 & 958 & 604 & 745 \\
\hline Średnia & $\mathbf{9 3 6 , 7}$ & $\mathbf{5 4 9 , 3}$ & $\mathbf{6 8 6}$ \\
\hline ZX70 Pr. nr 1 & 965 & 596 & 735 \\
\hline ZX70 Pr. nr 2 & 962 & 596 & 728 \\
\hline ZX70 Pr. nr 3 & 967 & 605 & 739 \\
\hline Średnia & $\mathbf{9 6 4 , 7}$ & $\mathbf{5 9 9}$ & $\mathbf{7 3 4}$ \\
\hline
\end{tabular}

Przeprowadzono również próbę zginania wg PN-EN ISO 5173:2011 [9]. Polega ona na zginaniu próbek od strony lica i grani spoiny do kąta $135^{\circ}$. Na rysunku 8 pokazano wymiary próbek.

Próbę zginania wykonano na maszynie wytrzymałościowej Instron 8502. Podczas próby zginania próbki obserwowano słabą sprężystość, uzyskując kąt zgięcia $120^{\circ}$

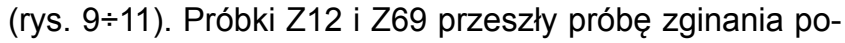
zytywnie (nie wystąpiły pęknięcia). Dwie próbki Z70 pękły przy zginaniu od strony lica. Wyniki próby zestawiono w tablicy $X$.



Rys. 8. Próbka do zginania

Fig. 8. Bent sample

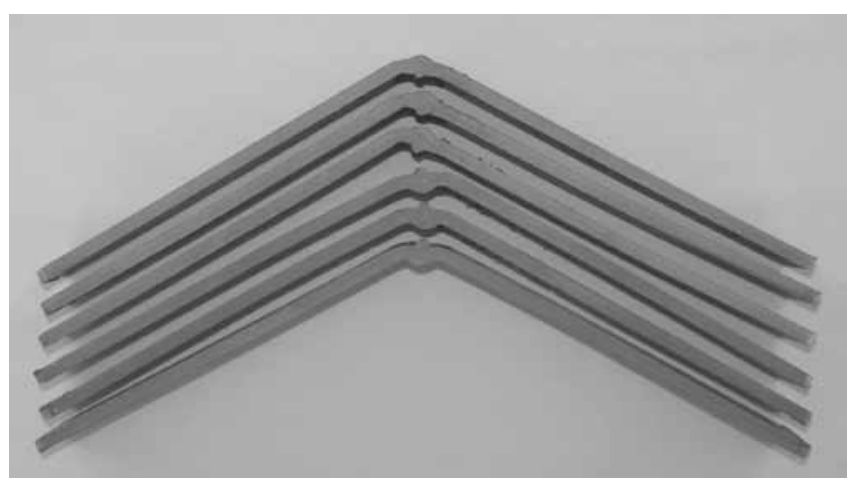

Rys. 9. Zgięte próbki Z12. Od góry: trzy próbki zgięte od strony grani, od dołu: trzy próbki zgięte od strony lica spoiny

Fig. 9. Bent samples Z12. From the top: three samples bent from the ridge side, from the bottom: three samples bent from the weld cap side 


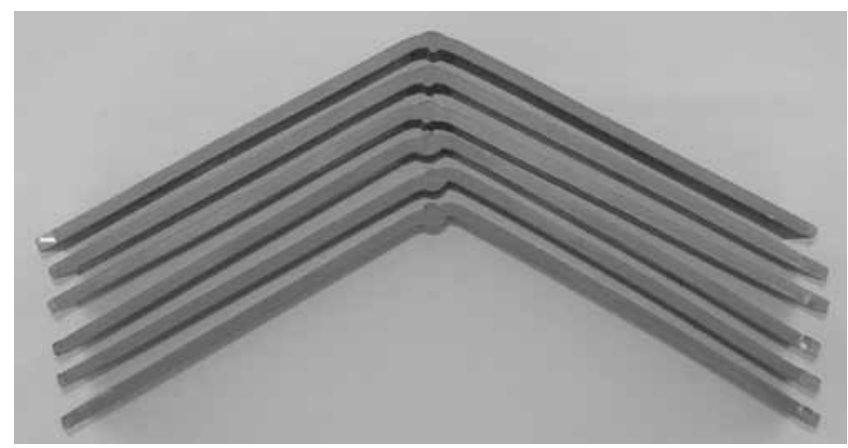

Rys. 10. Zgięte próbki Z69. Od góry: trzy próbki zgięte od strony grani, od dołu: trzy próbki zgięte od strony lica spoiny

Fig. 10. Bent samples Z69. From the top: three samples bent from the ridge side, from the bottom: three samples bent from the weld side
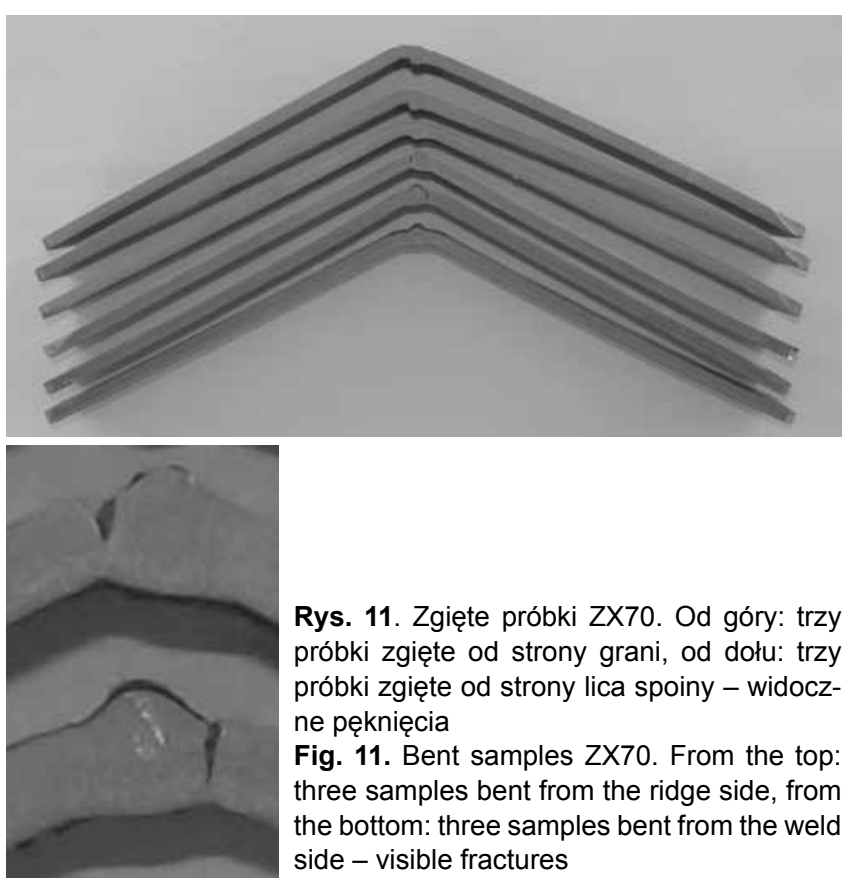

Rys. 11. Zgięte próbki ZX70. Od góry: trzy próbki zgięte od strony grani, od dołu: trzy próbki zgięte od strony lica spoiny - widoczne pęknięcia

Fig. 11. Bent samples ZX70. From the top: three samples bent from the ridge side, from the bottom: three samples bent from the weld side - visible fractures

Tablica X. Zestawienie wartości średnich po próbie rozciągania

Table X. Juxtaposition of mean values after tensile test

\begin{tabular}{|c|c|c|c|c|c|c|c|c|c|}
\hline \multirow[t]{2}{*}{ Materiał } & \multicolumn{3}{|c|}{$\begin{array}{l}\text { Wytrzymałość na rozciąganie } \\
\qquad \mathrm{R}_{\mathrm{m}}, \mathrm{MPa}\end{array}$} & \multicolumn{3}{|c|}{$\begin{array}{l}\text { Umowna granica } \\
\text { sprężystości } \mathrm{R}_{0,05}, \mathrm{MPa}\end{array}$} & \multicolumn{3}{|c|}{$\begin{array}{c}\text { Umowna granica } \\
\text { plastyczności } R_{0,2}, \mathrm{MPa}\end{array}$} \\
\hline & Z12 & Z69 & ZX70 & $\mathrm{Z} 12$ & Z69 & ZX70 & $\mathrm{Z} 12$ & Z69 & ZX70 \\
\hline $\begin{array}{c}\text { Boron } 27 \text { hartowany } \\
\text { spawany }\end{array}$ & 928,7 & 936,7 & 964,7 & 595,7 & 549,3 & 599 & 726 & 686 & 734 \\
\hline $\begin{array}{c}\text { Boron } 27 \text { hartowany } \\
\text { (materiał rodzimy) }\end{array}$ & \multicolumn{3}{|c|}{1678,0} & \multicolumn{3}{|c|}{962,5} & \multicolumn{3}{|c|}{1197,5} \\
\hline
\end{tabular}

\section{Podsumowanie}

W konstrukcjach spawanych wiele czynników ma wpływ na jakość złącza spawanego. Jednym z najważniejszych jest właściwy dobór spoiwa i parametrów spawania. W badaniach poświęcono wiele uwagi tym zagadnieniom. Spoiwo dobrano zgodnie $z$ wytycznymi, ale też skorzystano $z$ doświadczenia technologów spawalników i specjalistów firm produkujących materiały dodatkowe do spawania.

Parametry spawania ustalono doświadczalnie na podstawie badań wizualnych próbek. Dowodem na spełnienie wymagań są wyniki badań rentgenowskich spawanych płyt kontrolnych wykonane przez akredytowane, niezależne laboratorium.
Próba rozciagania pokazała, że stal Boron 27 - spawana w stanie zahartowanym - nie zachowuje się tak jak inne spawane materiały konstrukcyjne. Miejsce rozerwania próbek znajduje się w końcowej części strefy wpływu ciepła, co jest cechą charakterystyczną tylko dla tego przypadku.

Niezależnie od rodzaju użytego spoiwa właściwości mechaniczne są niemal identyczne dla wszystkich próbek. Wytrzymałość na rozciąganie stali borowej hartowanej i spawanej stanowi zaledwie ok. 54\% wytrzymałości hartowanego materiału rodzimego, podobnie jest w przypadku pozostałych właściwości zestawionych $\mathrm{w}$ tablicy $\mathrm{X}$.

\section{Literatura}

[1] Hebda M.: Procesy tarcia, smarowania i zużywania maszyn, Warszawa-Radom 2007

[2] Chalecki M., Czaplejewicz W., Pawłuszewicz A.: Spawanie stali hartowanych. Przegląd Spawalnictwa 12/2008.

[3] Materiały katalogowe firmy RUUKKI, www.ruukki.com.

[4] PN-EN ISO 14341:2011 Materiały dodatkowe do spawania. Druty elektrodowe i stopiwo do spawania łukowego elektrodą metalową w osłonie gazu stali niestopowych i drobnoziarnistych. Klasyfikacja.
[5] PN-EN ISO 17632:2011 Materiały dodatkowe do spawania. Druty elektrodowe proszkowe do spawania łukowego elektrodą metalową, w osłonie gazu i bez osłony gazu, stali niestopowych i drobnoziarnistych. Klasyfikacja.

[6] PN-EN ISO 14175:2009 Materiały dodatkowe do spawania. Gazy i mieszaniny gazów do spawania i procesów pokrewnych

[7] PN-EN ISO 17637:2011 Badania nieniszczące złączy spawanych. Badania wizualne złączy spawanych.

[8] PN-EN ISO 4136:2011 Badania niszczące złączy spawanych metali. Próba rozciągania próbek poprzecznych.

[9] PN-EN ISO 5173:2010 Badania niszczące spoin w materiałach metalowych. Badanie na zginanie. 